\title{
PROUČEVANJE MANJŠIN IN OBMEJNIH OBMOČIJ V ZGORNJEM JADRANU - RAZISKOVALNI PRISTOPI IN PROBLEMI V LUČI POLITIČNE GEOGRAFIJE
}

\author{
Milan Bufon \\ Univerza na Primorskem, Fakulteta za humanistične študije, Glagoljaška 6, 6000 Koper \\ e-mail: milan.bufon@upr-kp.si
}

Izvirni znanstveni članek

COBISS 1.01

\section{Izvleček}

Avtor obravnava kompleksnost manjšinskih in obmejnih vprašanj, ki sestavljajo problematiko proučevanja kontaktnih območij v zgornjem Jadranu, na katere delujejo sočasno različni dejavniki in prispevajo $\mathrm{k}$ oblikovanju različne pojavne tipologije $\mathrm{v}$ razmerju družbena dominantnost-manjšina, ki vključujejo stanja mejne nacionalne manjšine, teritorialne oziroma regionalne manjšine ter urbane manjšine. Območje zgornjega Jadrana se potrjuje kot izredno zanimiv "laboratorij" za uvajanje novih modelov pri utrjevanju različnih institucionalnih in vsakodnevnih oblik medetnične povezanosti v okviru EU.

Ključne besede: manjšine, obmejna območja, zgornji Jadran

\section{STUDY OF MINORITIES AND BORDER AREAS IN THE UPPER ADRIATIC: RESEARCH APPROACHES AND PROBLEMS IN LIGHT OF POLITICAL GEOGRAPHY}

\begin{abstract}
The author deals with the complexity of minority and border issues that make up the problem of studying contact areas in the upper Adriatic. The nexus of these issues is under the simultaneous influence of various factors contributing to the formation of different phenomenon typologies within the social dominance-minority relation, comprised of the situations of border national minority, territorial or regional minority and urban minority. Upper Adriatic has once again proven to be a most interesting "laboratory" for the introduction of new models in the consolidation of various institutional and everyday forms of inter-ethnic integration within the framework of the EU.
\end{abstract}

Key words: minorities, border areas, Upper Adriatic area 


\section{UVOD}

Iz vidika socialne in politične geografije, kateri je v slovenski geografiji postavil ustrezne temelje prof. Vladimir Klemenčič, gre poudariti najprej kompleksnost manjšinskega vprašanja, na katerega delujejo sočasno različni dejavniki, ki podajajo obenem neko hierarhično razporeditev družbenih in prostorskih odnosov med manjšino in njenim družbenim okoljem in jih lahko združimo v naslednje skupine:

- geopolitične razmere;

- meddržavni odnosi;

- medetnični odnosi;

- $\quad$ interni razvojni dejavniki.

Zgornji razpored izraža tudi neko stopničasto prehajanje od svetovne na lokalno raven, pri čemer moramo seveda upoštevati, da ima spričo svojega statusa in značaja manjšina največ možnosti vpliva na lokalni in regionalni ravni, se pravi v okviru zadnjih dveh izmed zgoraj navedenih kategorij. Po drugi strani pa ne gre zanemariti dejstva, da se z razvojem subjektivizacije manjšin v smislu prevzemanja samostojnejše družbene vloge povečujejo tudi možnosti poseganja na višjo, to je državno in mednarodno raven. Tako ima na primer institucionalizacija manjšinskega vprašanja na ravni Sveta Evrope ali EU, kjer pridobivajo manjšine na pomenu in so $\mathrm{v}$ določenem pogledu že tudi zastopane $\mathrm{v}$ nekaterih telesih, $\mathrm{za}$ posledico dejstvo, da se izboljšujejo tudi lokalne oziroma regionalne razmere, v katerih se manjšine konkretno nahajajo, vse to pa spet vpliva na to, da se posledično povečuje tudi vloga manjšin na širši meddržavni in mednarodni ravni.

V nadaljevanju bom poskusil na primeru lastnih raziskovalnih opažanj na kratko orisati, kako se zgoraj omenjene ključne determinante manjšinskega položaja izražajo na primeru proučevanja manjšin in obmejnih območij v zgornjem Jadranu in katere perspektive odpirajo sodobni razvojni procesi v okviru teh determinant.

\section{GEOPOLITIČNE RAZMERE}

Verjetno je etnično mešani in obmejni prostor zgornjega Jadrana eden izmed evropskih območij, na katerega so geopolitične razmere najbolj usodno in trajno vplivale. Ta prostor namreč sekata kar dve pomembni geopolitični delitveni črti: na eni strani je to geopolitična razmejitvena linija med obema povojnima blokoma in poteka v smeri sever-jug, po drugi pa kulturno-civilizacijska meja, v okviru katere lahko tudi razlikujemo vertikalni in horizontalni potek. Družbeno-politična meja je delila zahodne liberalne demokracije od komunističnih oziroma socialističnih družb, družbeno-kulturna meja pa "zahodno" civilizacijo z jasno državno-nacionalno profiliranostjo od "vzhodnega", pretežno slovanskega civilizacijskega okolja z nižjo stopnjo državno-nacionalne profiliranosti. Dodatna družbeno-kulturna meja je znotraj "vzhodnega" bloka delila severozahodni katoliško-protestantski del, ki je v preteklosti intenzivno komuniciral $\mathrm{z}$ razvitejšim delom Evrope, ter vzhodni in južni pravoslavno- 
muslimanski del, ki je bil vključen v ruski oziroma turški imperij. Seveda so to le grobi obrisi, saj smo imeli znotraj "zahodnega" bloka dokaj labilno italijansko situacijo, kjer je zato dolga leta vladala prava politična blokada, znotraj "vzhodnega" bloka pa tudi izjemno jugoslovansko situacijo, v kateri se je vsaj delno uresničila Churchillova vizija "fifty-fifty" vpliva in je bila zato Jugoslavija deležna izdatne materialne pomoči iz "zahoda" v podobni meri, kot so je bile deležne države Marshallovega plana.

Pretekle razmere in povojni potek geopolitičnih meja v Evropi so zato močno vplivale na položaj Slovencev v Italiji ter Italijanov v slovenski in hrvaški Istri. Povezovanje družbeno-politične meje z družbeno-kulturno je povzročila, izhajajoč iz "zahodnega" oziroma italijanskega gledišča, tisto svojevrstno in značilno opredelitev te skupnosti z izrazom "Slavo-komunisti", ki ji je takorekoč zaprla vse razvojne možnosti in jo odrinila v nekakšen družbeni geto. Toda to še zdaleč ni bila edina meja, ki smo jo srečevali v tem prostoru, niti ne edina posledica širših geopolitičnih razmer na lokalni ravni. Sama manjšina je bila namreč razdeljena in je deloma gojila prozahodno orientacijo, kar ni bilo vselej in povsem istovetno s protikomunistično orientacijo, deloma pa projugoslovansko orientacijo, kar pa tudi ni bilo vselej in povsem istovetno s prokomunistično orientacijo. Resolucija kominforma je uspela to skupino v prvem povojnem obdobju še dalje razcepiti na proruski in proitalijanski komunistični del, ki je zajel večinoma proletarski in urbani del manjšine, ter na projugoslovanski del, v katerem so vztrajali zlasti intelektualci in podeželani. Pomembne delitve pa so obstajale tudi znotraj "belega" tabora, kjer je bilo mogoče zaslediti skupino izrazito protikomunistično in klerikalno orientiranih oseb, kakor tudi liberalno in socialdemokratsko skupino, ki sta to, večkrat protislovno, naravnanost skušali povezati z oblikovanjem ločene slovenske manjšinske stranke. Čeprav je bila v globalnem smislu celotna manjšina prva povojna desetletja v italijanskih "uradnih" očeh nič manj kot nekakšna "peta kolona", do katere so izvajali dokaj intenziven asimilacijski pritisk, je zgoraj opisana razparceliranost manjšinskega družbenega okolja ustvarila vrsto skorajda paradoksalnih situacij: v okviru manjšine večinski, projugoslovanski “rdeči” del, ki je zagovarjal potrebo po vključevanju v italijanske levičarske stranke, je bil funkcionalno povezan z jugoslovansko oziroma slovensko stranjo, vendar je bil v manjšini oziroma opoziciji v italijanskem političnem okolju; manjšinski "beli” del, ki je zagovarjal potrebo po ločeni manjšinski politični organiziranosti, je bil v opoziciji glede na jugoslovansko oziroma slovensko politično okolje, vendar pa je funkcionalno sodeloval z italijansko vladno krščanskodemokratsko stranko, ki sicer ni kazala nobene naklonjenosti do slovenske manjšine v Italiji. Po drugi strani so italijanske oblasti pripisale vsem tistim osebam, ki so se odločile, da po drugi svetovni vojni zapustijo Jugoslavijo in poiščejo »srečo« na »zahodu«, oznako militantnega »italijanstva«, ne glede na njihovo dejansko etnično in ideološko prepričanje, njihove rojake, ki so ostali na ozemlju Jugoslavije, pa preprosto »odpisali« kot »komunistične izdajalce «.

Povojna geopolitična delitev manjšinskega družbenega prostora je na ta način nenavadno dolgo vztrajala in je preživela celo "normalizacijo" italijanskega političnega prostora, kar gre pripisati tudi političnemu vplivu Slovenije po osamosvojitvi oziroma težnjam njenih političnih strank, da bi novo ali ponovno obujeno politično delitev slovenskega družbenega prostora na levosredinski (liberalni) in desnosredinski (konservativni) tabor “izvozili” tudi v zamejstvo, še toliko raje, ker so tu obstajali že vsi potrebni delitveni “predpogoji”. Vendar v geopolitičnem 
smislu danes ni več nikakršnih osnov za ohranjanje ideološke razklanosti manjšinskega družbenega okolja. To pomeni, da je vztrajanje na bipolarni manjšinski družbeni strukturi kot dediščini preteklih razmer dokajšnja "anomalija" v normaliziranih geopolitičnih razmerah, kateri bo potrebno v manjšini in širše posvetiti ustrezno pozornost (Bufon 2000a).

\section{MEDDRŽAVNI ODNOSI}

Pravkar povedano se $\mathrm{v}$ marsičem prepleta $\mathrm{z}$ vprašanjem meddržavnih odnosov in njihovega vpliva na manjšinski položaj. Če je bil na družbeno-politični ravni vpliv geopolitične delitve na razmere v današnjem slovensko-italijanskem obmejnem območju zelo močan, pa to ne velja za funkcionalne meddržavne oziroma čezmejne odnose (Bufon 2005). Obe strani sta se namreč zavedali nevarnosti "berlinizacije" južnega, urbaniziranega dela obmejnega pasu, kjer je državna meja razrezala dotlej enotne družbene prostore in sta zato že v mirovni sporazum iz leta 1947 vgradili nekaj "ventilov", ki naj bi omogočili ohranjanje določenih funkcionalnih vezi, predvsem na področju oskrbe mest Trsta in Gorice. Ta situacija je spodbudila sosednji državi k sprejetju enega izmed najbolj "zgodnjih” evropskih čezmejnih dogovorov (1949) o dvolastniškem mejnem prehajanju, ki je bil nato takoj po podpisu londonskega memoranduma in delitvi Svobodnega tržaškega ozemlja razširjen na celoten obmejni pas in na vse prebivalce tega pasu. Pomen videmskega sporazuma $\mathrm{z}$ odpiranjem posebnih lokalnih dvostranskih mejnih prehodov, ki je v naslednjih letih v bistvu povsem "liberaliziral” lokalni čezmejni režim, je še toliko večji, če pomislimo, da so bili vizumi za prehod italijansko-jugoslovanske meje odpravljeni šele sredi 60. let. Ob lokalnih medosebnih in drugih funkcionalnih vezeh na področju oskrbe, dela in preživljanja prostega časa so se tedaj povečale še gospodarske meddržavne izmenjave, ki so potekale preko obmejnega pasu, v katerem je prisotna slovenska manjšina v Italiji, ali se celo tu koncentrirale, kakor v primeru vpliva tržaškega nakupovalnega središča daleč v notranjost jugoslovanskega ozemlja (Klemenčič in Bufon 1991).

Slovenska manjšina v Italiji je v tem odpiranju meddržavnih funkcionalnih, predvsem ekonomskih izmenjav videla svojo možnost posredovanja in to posredovalno vlogo sta ji potihoma priznavali obe strani, zlasti pa še jugoslovanska oziroma slovenska stran, ki je v manjšini našla svojega idealnega "uvozno-izvoznega" agenta, ki bi s prevzemom nove gospodarsko-posredovalne funkcije obenem uspel nadomestiti pomanjkljivosti v svojem institucionalnem položaju. Ob nedvomno ugodnih posledicah te manjšinske "špediterske" funkcije, ki je preko manjšinskih finančnih ustanov s Tržaško kreditno banko na čelu vodila kar tretjino celotne jugoslovanske menjave z "zahodom" in ki je omogočila odpiranje novih delovnih mest, širjenje možnosti za rabo slovenskega jezika in večanje manjšinske samozavesti, a tudi oblikovanje določenih zametkov manjšinske regionalne politike s prenosom gospodarskih in kulturnih investicij $\mathrm{v}$ najbolj ranljiv in slaboten del manjšinskega družbenega okolja, to je $\mathrm{V}$ videmsko pokrajino, pa gre opozoriti tudi na njene negativne aspekte, ki so nazadnje $\mathrm{z}$ razkrojem manjšinske gospodarske strukture prišli jasno do izraza. Manjšinska gospodarskoposredovalna funkcija je bila namreč vse preveč labilna in enosmerna, saj je v celoti temeljila na pogojih družbeno-ekonomskega in družbeno-političnega nesorazmerja med sosednjima državama in bila poleg tega odvisna od stopnje politične tolerance ene in druge strani. 
V trenutku, ko so bila ta nesorazmerja odpravljena in ko je bilo politično pokroviteljstvo nad meddržavnimi gospodarskimi transakcijami umaknjeno, je manjšina funkcijo meddržavnega gospodarskega posredovanja izgubila, z njo pa tudi večji del svojih gospodarskih struktur.

Nove razmere v meddržavnih odnosih je prinesla osamosvojitev Slovenije leta 1991. Italijanska stran je v tistem času začela namreč dokaj pritiskati na domnevno v notranjezunanje političnem pogledu šibkejši novonastali državi, da bi okrepila svoj vpliv v Istri. To politiko pogojevanja je udejanila zlasti Berlusconijeva vlada, ki je povsem sprejela stališča istrskih optantov po ponovnem prevzemu nekdanjih nepremičnin v Istri, čeprav je to vprašanje razrešil že rimski sporazum med Italijo in Jugoslavijo leta 1983, po katerem se je slednja stran obvezala, da bo za opuščeno premoženje optantov izplačala ustrezno odškodnino. Tega in ostale mednarodne sporazume sta seveda ob osamosvojitvi sprejeli in izvajali tudi Slovenija in Hrvaška kot priznani naslednici Jugoslavije za njima pripadajoče državno ozemlje. Kot znano, je Italija ravno zaradi teh vprašanj dalj časa ovirala priključitveni proces Slovenije v Evropsko unijo in je to svojo politiko v odnosu do svoje vzhodne sosede bistveno revidirala le z nastopom Prodijeve vlade leta 1996, ki se je končno obvezala, da bo zakonsko rešila tudi položaj slovenske manjšine v Italiji, ki sicer na delu svojega naselitvenega ozemlja uživa status priznane narodne manjšine, a za katero ni bil sprejet noben okvirni zaščitni zakon, kakršen na primer varuje ne le frankofonsko manjšino v dolini Aoste ali nemško in ladinsko manjšino na Južnem Tirolskem, ampak tudi italijansko manjšino v slovenski in hrvaški Istri. Do izglasovanja tega zakona je sicer nato prišlo, nova desno-sredinska oblast v Italiji pa je njegovo izvajanje povsem onemogočila, tako da ostaja še vedno prisotna želja, da bodo nove mednarodne in regionalne razmere po vstopu Slovenije v EU naposled vendarle omogočile izpolnjevanje manjšinskih zahtev na ravni evropskih zaščitnih standardov.

Drugi aspekt sedanjega položaja slovenske manjšine v Italiji po osamosvojitvi Slovenije zadeva zato vprašanje, $\mathrm{v}$ kolikšni meri je slednja le objekt mednarodnih in bilateralnih dogovorov ali subjekt regionalnega in družbenega razvoja $v$ obmejnem območju ter dejavnik čezmejne integracije. Če je bilo v prvem obdobju po osamosvojitvi Slovenije zaznati tako na slovenski kot na italijanski strani določeno tendenco po instrumentalizaciji lastnih manjšin $\mathrm{v}$ iskanju novih regionalnih in mednarodnih ravnovesij, je v zadnjem času opaziti pri obeh državah drugačen, bolj "evropski” pristop, kar je posledica tudi korenitih sprememb, ki jih je doživel slovensko-italijanski obmejni in etnično mešani prostor. Po letu 1991 to ni več mejno območje med dvema družbeno in politično povsem različnima sistemoma, z vstopom Slovenije v EU pa je prišlo tudi do dejanskega odstranjevanja objektivnih administrativnih in subjektivnih psiholoških ovir, ki otežujejo čezmejni gospodarski, družbeni in kulturni pretok. In če je bila torej v preteklosti funkcija slovenske manjšine v Italiji usmerjena predvsem $\mathrm{k}$ gospodarskemu posredovanju med dvema družbeno-političnima različnima državama in sistemoma, je od razkroja Jugoslavije, osamosvojitve Slovenije in poenotenja političnih in družbeno-ekonomskih razmer na obeh straneh meje ta funkcija izgubila svoj smisel oziroma se je od mednarodne preusmerila na manjšini bolj prikladno regionalno raven. Vzporedno s tem pa se slovenski manjšini v Italiji, tako kot drugim obmejnim manjšinskim skupnostim v Evropi, odpirajo nove perspektive in nove naloge na področju čezmejne družbene in kulturne integracije in povezovanja (Klemenčič in Bufon 1994). To velja še posebej za južni del sedanje slovensko-italijanske meje, ki ga označuje dolgotrajna družbena in kulturna 
povezanost. V smislu dejanske čezmejne integracije in širjenja načel koeksistence, na katerih temelji ne le proces evropske integracije, temveč sodobna evropska civilizacija nasploh, je ob funkcionalnih aspektih čezmejnih gospodarskih izmenjav zato še posebno pomembno, da se $\mathrm{v}$ čim večji meri aktivirajo tudi družbene in kulturne oblike povezovanja in posredovanja. Le na ta način se uspejo oblikovati celovitejša in med seboj integrirana čezmejna območja, kjer meja izgubi svojo tradicionalno delitveno funkcijo in kjer se lahko tudi manjšinske kulturne in jezikovne "kontaktne" skupnosti polneje razvijajo.

V sorodnih zahodno-evropskih obmejnih območjih skušajo zgoraj povedano uresničiti z oblikovanjem posebnih institucionalnih čezmejnih teles, tako imenovanih evroregij, saj gre tam običajno za primere družbeno in kulturno manj prepustnih "starih" obmejnih območij, kjer je treba obmejno prebivalstvo tako rekoč šele privajati k čezmejnemu sodelovanju. Ni slučaj zato, če se za take oblike "institucionalnega" čezmejnega povezovanja močno ogrevajo v severnem delu slovensko-italijanskega obmejnega območja ob "stari" meji, medtem ko se v južnem delu nahajamo pred situacijo v bistvu "spontanega" čezmejnega prostora, kjer ljudje, kljub pomanjkanju ustreznih institucionalnih nadgradenj, že sedaj nadpovprečno intenzivno čezmejno komunicirajo ne le na gospodarskem, a tudi na družbenem in kulturnem področju. Značilno je tudi, da velik del takih oblik čezmejnega povezovanja tu vzdržujejo ravno manjšine, v prvi vrsti slovenska v Italiji, ki živi vzdolž celotnega mejnega pasu, čeprav za to svojo povsem "naravno", a zato nič manj pomembno funkcijo ne prejema nobenega posebnega priznanja ali spodbude.

\section{MEDETNIČNI ODNOSI}

Pri obravnavi nacionalnih in etničnih manjšin se često pozablja na dinamične in komplesne spemembe, ki jih vnašajo interetnični odnosi, kakor da bi bile te manjšine v njihovem družbenem in prostorskem položaju povsem statične in "obsojene" na večno reprodukcijo lastne podobe $\mathrm{v}$ prihodnje čase. V resnici so stvari bistveno drugačne: kot živi organizmi so manjšine v nenehnem preoblikovanju, še posebno v pogledu njihove družbene strukture in medetničnih odnosov. To se dogaja predvsem $\mathrm{z}$ modernizacijo družbene strukture, ki postavlja manjšine nekako pred dilemo, ali naj se vse bolj integrirajo v sodobno družbo ali pa naj se mobilizirajo okrog lastnih kulturnih značilnosti (Bufon 1992a). Večinoma je opaziti, da prihaja pri modernizaciji manjšinske družbe do svojevrstne sinteze obeh možnih ekstremov. Proces družbene modernizacije je namreč odločilno prispeval k porastu izobrazbene in socialno-ekonomske ravni manjšinske populacije, k povečevanju prostega časa in širjenju komunikacijskih sredstev ter izmenjavi informacij. Mnogokrat je v perifernih območjih do teh sprememb prišlo tako hitro (v smislu prehoda od agrarne v terciarno družbo), da slednje niso povzročile izrazitejše akulturacije manjšinskega prebivalstva, kakor je to značilno za etnično mešana urbana središča, temveč so celo pripomogle k temu, da je to prebivalstvo pridobilo nekatere dodatne elemente za mobilizacijo v prid svoje izvorne kulture.

Na primeru Slovencev v Italiji opažamo v tem pogledu dva temeljna in medseboj prepletena efekta procesa družbene urbanizacije oziroma modernizacije te skupnosti. Prvi se nanaša na prostorsko dimenzijo in širše regionalne odnose, v katere je vključena slovenska 
manjšina, drugi pa na njeno etnično in socio-ekonomsko strukturo. Oba skupaj lahko povežemo v nek enoten model etnično-regionalnega razvoja te nacionalne manjšine (Bufon 1994a).

1) V preteklosti je za sedanje slovensko poselitveno ozemlje v Italiji, ki ga je le na zahodu omejevala dokaj jasna etnična meja, sicer pa je bilo večinoma vključeno v razvijajoči se slovenski kulturni prostor, veljalo preprosto pravilo: podeželje je skoraj brez izjeme kompaktno naseljevalo slovensko kmečko prebivalstvo, urbani centri pa so bili narodnostno mešani. V tej začetni fazi med obema navedenima socio-ekonomskima in prostorskima enotama, se pravi med urbanimi središči in podeželjem, ni bilo kake večje izmenjave. V bistvu sta obe enoti živeli svoje ločeno avtarkično življenje oziroma nista prispevali k preoblikovanju ostale enote. To je bilo, skratka, obdobje statičnega sožitja dveh prostorsko in družbeno zaprtih enot: imobilnega agrarnega podeželja in samozadostnega urbanega centra, v katerem je prevladovala predkapitalistična oziroma predindustrijska ekonomija.

2) V naslednji fazi, v kateri je prišlo tudi do intenzivnih mednarodno-političnih sprememb in nastanka močno konfliktnih odnosov na ravni večina-manjšina, se stiki med slovenskim podeželjem in etnično mešanimi centri okrepijo, zlasti v obdobju razvoja industrializacije. Toda ta nov, odprtejši ekonomski sistem je s svojo selektivnostjo še ostreje načel vprašanje odvečnega kmečkega prebivalstva, ki se je, kjer je bilo mogoče, izseljevalo v bližnje urbane centre, sicer pa emigriralo izven lastnega avtohtonega ozemlja. To fazo lahko zato opredelimo kot obdobje uveljavljanja labilnih enosmernih procesov industrializacije in deagrarizacije, katerima se je pridružila še močna politična tendenca po nacionalni standardizaciji v okviru medvojne Italije. Narodnostna sestava podeželja se dejansko v tem času ni bistveno spremenila, pač pa se je z izseljevanjem slovenskega prebivalstva iz lastnega avtohtonega naselitvenega ozemlja v bližnja urbana in industrijska območja potencialno razširil obseg narodnostno mešanega ozemlja.

3) Zadnjo fazo označuje razmah terciarnih dejavnosti: vezi med mesti in podeželjem postajajo vse bolj intenzivne in obojestranske, kar prispeva k zmanjševanju kvalitativnih razlik med obema enotama. Ob uveljavljanju skupnega, urbanega načina življenja ostajajo razlike največkrat le funkcijskega značaja. Pretok prebivalstva je $\mathrm{v}$ tej fazi obojesmeren in pojavlja se celo porast števila prebivalstva na podeželju, kamor se spričo ugodnejših življenjskih razmer naseljujejo zlasti višje socialne skupine. V tej fazi prostorsko odprtega in stabilnega formiranja urbane družbe prihaja tako do precejšnjega preoblikovanja etnične sestave podeželja zaradi priseljevanja neavtohtonega prebivalstva, ki pa se obnaša povečini kot porabnik tega prostora, medtem ko slovenska manjšina tu ostaja ali komajda postaja upravljalec svojega poselitvenega ozemlja, zlasti tedaj, ko se z rastjo njene ekonomske podlage povečuje tudi njena družbena in politična vloga.

Seveda se navedene faze regionalnega in etničnega razvoja niso odvijale na celotnem narodnostno mešanem ozemlju z enako hitrostjo in intenzivnostjo. V povojnem času je prišlo večinoma do prepletanja zadnjih dveh zgoraj orisanih faz: medtem ko je v okolici večjih mest že prišlo do urbane organizacije prostora in družbe, so drugod še vedno prisotni labilni 
procesi, ki jih je sprožila industrializacija ravninskih predelov. Iz etničnega vidika se zdi prav ta faza najbolj kritična, pa čeprav ne povzroča takojšnjih strukturnih sprememb, saj vodi po eni strani k demografski eroziji avtohtonega slovenskega ozemlja in v skrajni konsekvenci do propada celotne kulturne pokrajine, po drugi strani pa k širjenju manjšinskega prebivalstva na neavtohtono ozemlje, kar ima spet lahko različne posledice. Depopulacija avtohtonega slovenskega ozemlja je posebno zaskrbljujoča tudi zato, ker normativno-zaščitni ukrepi, ki bi jih morali državni organi sprejeti tudi v prid slovenske manjšine, temeljijo povečini na teritorialnem principu, se pravi, da veljajo le za historično slovensko naselitveno ozemlje, kjer izkaže manjšina zadostno konsistenco. To ozemlje pa ima celo za izseljene pripadnike manjšine pomembno identifikacijsko vlogo, čeprav predstavlja umik iz avtohtonega ozemlja večinoma tudi izgubo lastne kulturne podlage in korak k asimilaciji. Po drugi strani pa lahko prav izseljeniška izkušnja z odkritjem etničnega "pluralizma" med izseljenci prispeva k spoznavanju lastne etnične in kulturne "različnosti" in torej h krepitvi narodnostne zavesti.

Obenem se z rastjo družbene in prostorske mobilnosti bistveno spremeni podoba nekdaj jasne etnične meje, okrog katere se sedaj oblikuje nov družbeni fenomen tako imenovanega "etničnega kontinuuma". Vsekakor je etnična meja v svojem podrobnem poteku že v preteklosti doživljala nenehne spremembe in korekture, vendar je v svojih osnovnih obrisih vendarle ostala dokaj konstantna vse do nastopa "modernizacije". Jasno je, da je pojem avtohtonega manjšinskega naselitvenega ozemlja ostal bolj ali manj nespremenjen, toda to ozemlje sedaj ne omejuje več neka "realna" etnična linija, ampak ostaja zgolj kot "kulturna dimenzija", znotraj katere pa se glede etnične opredelitve in samoopredelitve odpirajo najrazličnejši novi problemi. V obdobju "klasične" etnične delimitacije pred nastopom "modernizacije" etnično opredeljevanje $\mathrm{v}$ resnici ni povzročalo večjih težav in se je često povsem poistovetilo $\mathrm{S}$ teritorialnim ali regionalnim opredeljevanjem. S postopnim uveljavljanjem modernizacije, ki je težila k večji funkcionalni povezanosti vseh v določeno politično enoto zaobjetih območij, pa je bil lokalni jezik v čedalje večji meri izločen iz javne prakse, se pravi predvsem iz upravnih in šolskih struktur, ki so bile pretežno koncentrirane v urbanih središčih. Ta težnja je v prvi polovici tega stoletja prerasla v pravo fašistično preganjanje vsake oblike jezikovne "drugačnosti", kar je privedlo do skrajnih oblik nasilnega zatiranja jezikovnih manjšin in njihove asimilacije oziroma "čiščenja". Manjšinskemu jeziku je bila na ta način odvzeta njegova temeljna družbena razsežnost in njegova uporabnost se je omejevala le na družinske ali vaške govorne položaje. S tem je seveda njegova pozicija na vrednostni lestvici močno nazadovala, še toliko bolj v tistih območjih, kjer je manjšinski, lokalni jezik nezaščiten in nezastopan $\mathrm{v}$ šolskem sistemu. $\mathrm{V}$ takih razmerah je manjšinskemu jeziku usojeno, da izgine tudi iz družinskih okolij, in regredira na pozicijo "izvorne lokalne govorice" z zgolj folklorno konotacijo.

Povedano se kar dobro prilega razmeram Slovencev v Italiji: na eni strani imamo situacijo videmske pokrajine, kjer je bila državna asimilacijska dejavnost posebno dolgotrajna, tukajšnje slovensko prebivalstvo pa ni bilo vključeno $\mathrm{v}$ slovenski nacionalni preporod $\mathrm{v}$ okviru Avstrije, na drugi strani pa situacijo Slovencev na Goriškem in Tržaškem, ki so sicer uspeli "ohraniti” šole s slovenskim učnim jezikom, a kjer je slovenščina izločena iz vseh preostalih "javnih” govornih položajev. Neenakost javne jezikovne prakse so skušali Slovenci $\mathrm{v}$ teh predelih nadomestiti z ustanavljanjem velikega števila docela slovenskih asociativnih 
središč na teritoriju. Vendar pravi problem ostajajo tu urbani centri, ki se še nadalje vedejo kot nekakšne asimilacijske "črne luknje”, še zlasti do družbeno-ekonomsko šibkejših slojev, ki jih je deagrarizacija slovenskega podeželja potiskala vanje. Ob izteku te prve "modernizacijske" faze pa se je pričela naslednja, ki teži k širjenju družbene urbanizacije na podeželje in s tem sproža zelo intenzivno družbeno in prostorsko mobilnost med obema enotama, kar je dejansko zabrisalo nekdaj "realno" etnično mejo (Bufon 1992b).

Vsi ti procesi, ki so se odvijali na nekem asimilacijskem kontinuumu, so v razmerah družbene neenakopravnosti slovenskega jezika in njegovih nosilcev povzročili skrajno problematizacijo narodnostnega ali bolje etničnega opredeljevanja, saj sta bila pripadnikom manjšinske etnične skupnosti v mnogih primerih odvzeta dva temeljna opredelitvena atributa: jezik in kulturno obzorje. Ostaja tako le etnična izvornost, a le v primeru, ko bi bila manjšinska skupnost v svojem reproduciranju docela zaprta, kar pa seveda ni bila niti v preteklosti, kaj šele danes. V čedalje večji meri se problem etničnega opredeljevanja srečuje z "nerešljivimi" primeri interetnične amalgamacije (otroci ponavljajočih se mešanih zakonov), ki so bili nekdaj prisotni le v urbanih središčih, a so se danes razširili že tudi na njihovo gravitacijsko zaledje. V takih primerih ne moremo več uporabljati “objektivnih" opredelitvenih kriterijev (na primer: po starših Slovenec), ampak le "subjektivne" (na primer: Slovenec po lastnem opredeljevanju). Očitno je v čedalje večjem številu primerov odgovor na vprašanje o etnični pripadnosti odvisen od muhavosti življenjske usode in je vse prej kot konstanten, saj lahko ista oseba v določenem obdobju svojega življenja izrazi pripadnost eni etnični skupini, v naslednjem pa drugi, mnogokrat pa je opredelitev v stilu "ali-ali" tudi povsem nemogoča, saj lahko mnoge osebe občutijo hkratno pripadnost dvema ali celo več etničnim skupinam, seveda preko različnih asociativnih vezi. Odgovori pa nihajo tudi glede na trenutno družbeno in politično klimo, ki je lahko bolj ali manj odprta do manjšinske problematike, odvisni so nadalje od jezika, v katerem se zastavljajo vprašanja, in od številnih drugih dejavnikov.

Vzemimo v ilustracijo etnolingvistične situacije obmejnega in etnično mešanega pasu Furlanije-Julijske krajine sondažo, ki jo je pred leti za Slovenski raziskovalni inštitut izvedla neka specializirana italijanska ustanova. Iz opravljenih anket izhaja v prvi vrsti to, da je delež “izjavljenih" Slovencev povsod precej nižji od deleža "potencialnih" Slovencev, največja pa je ta razlika v videmski pokrajini, kjer jezikovna pripadnost zaradi znanih asimilacijskih procesov ne korelira več (ali še) z narodnostno. Temu nasprotno pa je, zlasti na Tržaškem, delež “izjavljenih” Slovencev višji od deleža oseb, ki v družinskem krogu govore slovensko, kar priča o tem, da je zaradi višje nacionalne zavesti tu "slovenstvo" persistentnejše tudi v primerih mešanih zakonov. Toda očitno sama jezikovna praksa ne more dati zadovoljivega odgovora glede potencialnega deleža slovenskega prebivalstva, saj slovensko razume $\mathrm{v}$ povprečju skoraj $15 \%$ vseh prebivalcev obmejnega pasu, medtem ko ta jezik doma govori v povprečju le nekaj nad $10 \%$ teh prebivalcev, kar po eni strani pomeni, da se je v zadnjih desetih letih uporaba slovenskega jezika v domačem okolju med njegovimi potencialnimi nosilci drastično zmanjšala, po drugi pa pomeni tudi to, da se je delež "potencialnih" Slovencev vendarle povečal in obsega danes konsistenten del obmejnega prebivalstva. Delež "potencialnih" Slovencev se še zviša, če za osnovo vzamemo jezikovno znanje staršev, se pravi "izvorno" etnično pripadnost intervjuvanih. V tem primeru odkrijemo, da izhaja iz docela ali delno slovenskih družin v povprečju nad $25 \%$ obmejnega prebivalstva; v kolikšni 
meri pa se ta "potencialnost" prenaša tudi v naslednjo generacijo, pove podatek, da slovenski jezik obvlada, se pravi govori ali razume, v povprečju okrog $20 \%$ otrok intervjuvanih. Zelo pomemben je podatek o obiskovanju slovenskih šol, saj je ta $\mathrm{v}$ zadnjem desetletju doživel tudi najbolj korenito spremembo: delež otrok, ki so v celoti ali le deloma obiskovali slovenske šole, se je od okrog $15 \%$, povečal na preko $35 \%$, k čemur je prispeval zlasti povečan interes za obisk vrtcev in osnovnih šol s slovenskim učnim jezikom. Na ta fenomen je opozorila tudi novejša raziskava o slovenskem šolstvu, ki jo je opravil Slovenski raziskovalni inštitut, kar postavlja slovensko manjšino v povsem nov položaj in terja od nje tudi nov oziroma spremenjen pristop pri odzivanju na povečan interes po slovenskem jeziku in kulturi $\mathrm{v}$ obmejnem pasu, a hkrati izdatnejše napore za to, da se ta interes razvije tudi v povečane možnosti za rabo manjšinskega jezika tako v domači kot "javni”" sferi tega etnično mešanega družbenega okolja (Bufon 1998).

Različne asociativne vezi do slovenskega elementa med prebivalci ozemlja, v katerem je zgodovinsko prisotna slovenska manjšina v Italiji, odpira zelo različne možnosti določevanja ali ocenjevanja slovenske numerične konsistence. Slednjo lahko torej postavimo med dve skrajni števili: numerični minimum (okrog 30 tisoč oseb) dobimo, če kot Slovence opredelimo le tiste, ki se za take tudi izjavljajo, kar nam že samo po sebi zelo jasno govori o posledicah preteklih in sedanjih oblik izvajanja jezikovne in družbene neenakopravnosti; numerični maksimum (nad 150 tisoč) pa dobimo, če za osnovo vzamemo obiskovanje slovenskih šolskih struktur, kar nam, bolj kot dimenzijo obsega mešanih zakonov, razgrne obseg okolja, v katerem je lahko slovenski element prisoten v potencialni ali zgolj latentni obliki. Razmerje med obema številoma nam nudi podatek, da je slovenščina dejansko v rabi le v 15\% družinskih okolij s potencialno slovensko prisotnostjo. Če kot nekakšno "zlato sredino” opredelimo družinska okolja, v katerih pride do medgeneracijskega jezikovnega prenašanja, dobimo število okrog 90 tisoč pripadnikov slovenske etnične skupnosti v Italiji, kar pomeni, da se le slaba tretjina posredno "ugotovljenih" Slovencev za take tudi eksplicitno izjavlja.

\section{RAZVOJNI DEJAVNIKI V OKVIRU MANJŠIN}

Kakšno vlogo naj torej imajo manjšine, kakršna je slovenska v Italiji, v meddržavnih odnosih? To vprašanje se nenavadno prepleta že z njenim statusom. Če slovensko skupnost v Italiji opredelimo kot nacionalno manjšino, kar večinoma tudi je, pomeni to, da je ta skupnost del nekega naroda, ki je zaradi različnih zgodovinskih in političnih okoliščin ostal izven politično-teritorialnih meja svojega matičnega naroda, ko se je ta prelevil v nacijo, a ga s slednjim vendarle povezuje enovita in sklenjena poselitvena distribucija, skupni zgodovinski in politični razvoj ter zlasti skupni kulturni elementi z jezikom na čelu. Termin nacionalne manjšine je med vsemi tudi najbolj prisoten v praksi mednarodnega prava, saj se je zlasti v drugi polovici 19. in v prvi polovici 20. stoletja ob spreminjanju politične podobe Evrope splošno uveljavilo mednarodnopravno načelo varstva manjšin, za katerega so večinoma poskrbele bilateralne pogodbe na osnovi nekaterih skupnih mednarodnih varstvenih izhodišč. Očitno pa načelo varstva nacionalnih manjšin ni bilo toliko sad humanih in demokratičnih razglabljanj in teženj, temveč zlasti element mednarodne stabilnosti in miru, saj so bile prav 
nacionalne manjšine največkrat predmet mednarodnih kriz in izgovor za različne vojaške intervencije. Termin nacionalne manjšine zato implicitno opredeljuje to družbeno enoto kot povsem identično $\mathrm{z}$ matičnim narodom $\mathrm{v}$ političnem, kulturnem, socialnem in celo ekonomskem pogledu. In take lastnosti so nacionalne manjšine v času do srede 20. stoletja tudi imele, saj so se večinoma predstavljale kot nekakšen "pomol" ali preprost podaljšek nekega naroda znotraj sosednje politične tvorbe oziroma nacije. S časom pa so se te tesne vezi med nacionalno manjšino in njenim matičnim narodom začele vsebinsko spreminjati: po eni strani je prišlo do družbene integracije nacionalnih manjšin v večinsko okolje, po drugi pa do družbene emancipacije same nacionalne manjšine, ki je tako preraščala iz političnega objekta v politični subjekt.

Toda nacionalne ali obmejne manjšine lahko v vsebinskem smislu opredelimo tudi kot avtohtone etnične manjšine z mednarodno razsežnostjo. Tako kot druge historične etnične manjšine, čeprav so običajno prisotne $\mathrm{v}$ manj obsežnih prostorih, imajo tudi nacionalne manjšine močno poudarjeno teritorialno zakoreninjenost, se pravi, da so lastni naselitveni prostor s svojo dolgotrajno dejavnostjo tudi kulturno zaznamovale ter preoblikovale $\mathrm{v}$ samosvojo kulturno pokrajino. Ker pa je pri nacionalnih manjšinah izrazitejša njihova mednarodna razsežnost, se pri teh skupnostih srečujemo z dinamičnim prepletanjem splošnih ali zunanjih regionalno-razvojnih dejavnikov z lokalnimi ali notranjimi etnično-regionalnimi elementi. Pri tem odigra posebno vlogo “objektivna” danost v smislu prehodnosti političnih meja in čezmejne družbene povezanosti, ki izhaja povečini iz razmer predhodnega skupnega življenja v enotnem družbenem okolju. Najbolj izrazit in trajen primer takega okolja je v slovensko-italijanskem obmejnem območju Goriška, medtem ko so se prostorske vezi na Tržaškem preusmerile proti jugu v začetku tega stoletja ter po zadnji razmejitvi spričo obsežnih migracijskih tokov na politično-etnični, a tudi ekonomski osnovi iz Istre proti Trstu. Drugod so potenciali, ki jih vnašajo lokalni socialni in kulturni elementi čezmejnega povezovanja zaradi dolgotrajnega obstoja razmejitvene črte, ki se je tu z izjemo trbiškega kota oblikovala že v 16. stoletju, slabše prehodnosti meje zaradi njenega orografskega značaja in manjše stopnje družbene urbanizacije obmejnega prebivalstva, bistveno manjši.

Seveda je ob lokalni dimenziji čezmejnih odnosov pomembna tudi njihova makroregionalna razsežnost (Bufon 2000b). Tako imamo primer, kakršen je trbiški, kjer skromnejše lokalne čezmejne vezi močno prekašajo tranzitni blagovni in oskrbni tokovi; na drugi strani so območja z zelo poudarjenimi lokalnimi vezmi in šibkejšimi tranzitnimi tokovi (Goriška). Vmesne primere predstavljajo območja, kakršno je tržaško, kjer sta oba elementa bolj ali manj enakomerno razvita, in območja, kjer so skromni tako lokalni kot tranzitni čezmejni tokovi (Rezija in Beneška Slovenija). Čeprav je makroregionalna čezmejna tranzitnost zelo učinkovita pri "sistemskem" odpiranju obmejnih območij širšemu prostoru, pa bi težko rekli, da usodneje vpliva na oblikovanje medseboj integriranih obmejnih območij v pravcato "obmejno regijo". Tranzitni tokovi namreč praviloma potekajo med centri posameznih makro-sistemov in na konkretne razmere odgovarjajočih obmejnih predelov ne posegajo veliko, razen $\mathrm{v}$ pogledu njihovega prostorsko-ekološkega obremenjevanja, ki je večkrat bolj negativno kot pozitivno. Toda v to makro-dimenzijo se lahko na različen način vključujejo tudi lokalne skupnosti in manjšine. Pri tem smo spet priče prepletanju dveh različnih socialnih in prostorskih statusov teh manjšin, ki smo jih opredelili kot "lokalne skupnosti s čezmejno dimenzijo", zlasti na socialnem 
in kulturnem področju v prostorsko ne preveč obsežnem območju, a tudi kot "nacionalne manjšine" v klasičnem smislu nekakšnih nacionalnih pomolov v sosednjih "ozemeljskih vodah". Ta vloga, kot smo videli, v razmerah velikih sistemskih družbeno-ekonomskih disparitet med sosednjima državama, lahko manjšinam odpira dodatne razsežnosti, a prinaša tudi dodatne nevarnosti. Na splošno je manjšinski družbeni interes $\mathrm{v}$ pogledu čezmejnega povezovanja $\mathrm{v}$ "normalnih" razmerah pretežno usmerjen na lokalno ali regionalno raven, kar manjšine od "nacionalne" in meddržavne dimenzije močno približuje "lokalni" in "regionalni" ravni in jih enači z drugimi lokalnimi skupnostmi. V tem okolju dobivajo predvsem zaradi kulturnih afinitet s sosednjo stranjo zelo pomembno vlogo družbenega "lepila" oziroma družbenih integracijskih dejavnikov, kar jim omogoča oblikovanje samostojnejše pozicije v spodbujanju in vzdrževanju družbeno-kulturnih meddržavnih izmenjav na lokalni in regionalni ravni. A to je lahko dokaj nelahek "posel”: če se manjšine kot "objekti” mednarodnega obračunavanja lahko zelo hitro znajdejo v položaju političnih "talcev", prihajajo kot "subjekti” lahko prav tako hitro v konflikt ne le $\mathrm{z}$ večinsko družbo oziroma njenim birokratsko-političnim aparatom, ampak tudi z istim aparatom svojega matičnega naroda. Sicer pa nam neko možno tipizacijo manjšinskih situacij v zgornjem Jadranu daje spodnja razpredelnica.

Glede družbenih in prostorskih problemov ter perspektiv manjšin lahko na primeru Slovencev v Italiji ugotovimo, da je ta manjšina v bistvu družbeni konglomerat različnih lokalnih in regionalnih prostorov in identitet kot rezultat pretekle delitve in povezovanja, se pravi, da je hkrati »mejna in »lokalna« manjšina, kar odpira resno vprašanje njene notranje integracije ter različnih sočasnih oblik povezovanja $\mathrm{z}$ matičnim in večinskim družbenim prostorom na lokalni in širši regionalni ravni. Po drugi strani tudi sočasno niha med položajem sodobne "urbane" in "potopljene» manjšine, saj jo označuje visoka stopnja koncentracije v urbanih središčih ter posledično hitro potencialno vključevanje v družbene razvojne procese, obenem pa ta integracija ob pomanjkanju ustreznih instrumentov in razvojnih politik povečuje probleme njene objektivne in subjektivne identifikacije. Njene razvojne možnosti omejuje dejstvo, da je le delno »teritorialna" in vse bolj "virtualna manjšina, saj lahko kot širše sklenjeno slovensko etnično ozemlje v Italiji opredelimo le Beneško Slovenijo z Rezijo, kjer pa so pretekli asimilacijski dejavniki doprinesli bistveni razmik mede »objektivno« in "subjektivno « etnično pripadnostjo tu živečih prebivalcev. Po drugi strani je bolj zavednim Slovencem na Tržaškem in Goriškem proces oblikovanja urbanega interetničnega kontinuuma manjšini onemogočil, da bi na svojem naselitvenem ozemlju uveljavila nek avtonomnejši model družbenega in prostorskega razvoja. Z normalizacijo interetničnih ter meddržavnih odnosov pa je pri tej manjšini opaziti tudi navidez protislovno prehajanje iz statusa »nacionalne« manjšine v status »etnične manjšine ter iz statusa »tolerirane» manjšine v status »priznane» manjšine, čeprav je glede institucionalnega položaja slovenske manjšine v širšem družbenem kontekstu treba reči, da se slednjo žal še prevečkrat obravnava kot nekakšen "tujek" tako znotraj deželnega kot mednarodnega družbenega prostora.

Teh nekaj primerov nam pove, kako je pri proučevanju manjšinskih problemov pomembno najprej ugotoviti akterje, dejavnike in procese, ki zadevajo posamezne manjšinske situacije in njihovo evolucijo. Slovenska geografija je na primer s pomočjo socialnogeografske metodologije pričela spremljati preobrazbo slovenskega podeželja v okviru procesov industrializacije, urbanizacije in deagrarizacije. Na tej osnovi je lahko obravnavala tudi socialno- 
ekološke strukturne probleme modernizacije in transformacije slovenskega naselitvenega prostora ter poglabljala politično- in etničnogeografske probleme v kontekstu skupnega slovenskega prostora in njegovega geopolitičnega položaja (Bufon 1997).

Problemska tipizacija manjšin v zgornjem Jadranu ter njihovih razvojnih možnosti

\begin{tabular}{|c|c|}
\hline Tip manjšin & Razvojne situacije \\
\hline Mejna nacionalna manjšina & $\begin{array}{l}\text { a) } \text { Situacija »pomola v tujem morju« ali »pete kolone« } \\
\text { - } \quad \text { Popolna odvisnost od matične države in istovetenje z njo; } \\
\text { - } \quad \text { Avtoizolacija, minimalna toleranca ali segregacija; } \\
\text { - } \quad \text { Težnja po asimilaciji s strani dominantne skupnosti. } \\
\text { b) Situacija »mostu« } \\
\text { - } \quad \text { Posredovanje med matično državo in državo »gostiteljico« na } \\
\text { - } \quad \text { Pocioekonomskem in sociokulturnem področju; } \\
\text { Priznana družbena in prostorska vloga in urejen pravni status. }\end{array}$ \\
\hline $\begin{array}{l}\text { Lokalna (regionalna) etnična } \\
\text { manjšina }\end{array}$ & $\begin{array}{l}\text { a) Situacija »oblegane trdnjave« } \\
\text { - } \quad \text { Zavračanje zunanjih stikov zaradi strahu pred asimilacijo in } \\
\text { homogenizacijo; } \\
\text { - } \quad \text { Avtoizolacija in težnja po folklorizaciji v odnosu } \\
\text { do drugih etničnih skupin, če je manjšina dovolj močna. } \\
\text { b) Situacija »srečnega otoka« } \\
\text { - } \quad \text { Priznana avtonomija in lokalno-regionalna vloga v družbenem, } \\
\text { kulturnem in prostotrskem pogledu; } \\
\text { - Povezovanje sodobnih razvojnih teženj z ohranjanjem jezikovne in } \\
\text { kulturne dediščine. }\end{array}$ \\
\hline $\begin{array}{l}\text { Urbana ali urbanizirana } \\
\text { manjšina }\end{array}$ & $\begin{array}{l}\text { a) Situacija »virtualne večjezične skupnosti« } \\
\text { - } \quad \text { Manjšina ne zavzema opaznega teritorialnega ozemlja, vendar se s } \\
\text { pomočjo sodobnih informacijskih sredstev povezuje v dvojezično in } \\
\text { močno integrirano skupnost; } \\
\text { - } \quad \text { Promocija manjšinske kulture in jezika ter različnih storitev in } \\
\text { proizvodov z manjšinskim »zaščitnim znakom« in ustrezno } \\
\text { razpoznavnostjo; } \\
\text { - Ohranjanje etnično mešane oziroma multikulturne družbene in } \\
\text { prostorske strukture in razvijanje družbenega modela »povezanosti v } \\
\text { različnosti«. } \\
\text { b) Situacija »potopljene skupnosti« } \\
\text { - Manjšina zaradi asimilacije, družbene, ekonomske in politične odvisnosti } \\
\text { oziroma podrejenosti ter slabe izobraženosti in organiziranosti izgublja } \\
\text { izvorne značilnosti; } \\
\text { Širjenje »sive cone«, postopna asimilacija in nastanek »vindišarske«, } \\
\text { družbeno in statusno zaznamovane večjezične skupnosti. }\end{array}$ \\
\hline
\end{tabular}


V resnicipajepoložaj “kontaktnih”etničnihinjezikovnihmanjšinobslovensko-italijanski meji danes bistveno različen od preteklosti. Izkazalo se je, da gre za močno urbanizirane, prostorsko in družbeno mobilne skupnosti, ki so zato v svojem okolju tudi močno integrirane. Ta integracija pa se ne kaže le v negativnem smislu asimilacije k večinski skupnosti, ampak v čedalje opaznejši meri tudi v ustvarjanju nekega novega "etničnega kontinuuma" oziroma multikulturne skupnosti, $\mathrm{v}$ kateri sta oba etnična in kulturna elementa enakovredneje prisotna drug ob drugem. Za razliko od preteklosti se $\mathrm{v}$ ta multikulturni družbeni prostor v vse večji meri vključujejo tudi pripadniki večinske skupnosti, med temi velikokrat tudi tisti, ki izhajajo iz že asimiliranih slovenskih družin. Ta proces povečuje deasimilacijo "potopljenega" dela manjšine in s tem krepi manjšinski demografski ciklus oziroma proces družbene reprodukcije manjšinske skupnosti, katerega dopolnjuje še priseljevanje iz matičnega ozemlja. Pričakovati je, da se bosta $\mathrm{z}$ odstranjevanjem objektivnih in subjektivnih mejnih pregrad oba elementa še okrepila in bo zato potreba po slovenskem jeziku in kulturi v etnično mešanem urbanem okolju toliko večja (Bufon 2003).

To se pravi, da se bo v bodoče regionalna funkcija obmejnih mest, kakršni sta Trst in Gorica, povečala le takrat, ko bosta obe mesti začeli razvijati svojo multikulturno podobo. Tega se lokalne, v večji meri pa tudi centralne italijanske oblasti polagoma vendarle začenjajo zavedati, kakor tudi dejstva, da bosta morali za to, da se širi italijanski družbeno-ekonomski vpliv v vzhodno zaledje, obe mesti ponovno postati nekoliko bolj "slovenski” oziroma da se bo v njih moral slovenski element okrepiti tudi "institucionalno". Poseben razvoj bo v situaciji odstranjevanja mejnih ovir doživelo tudi šolstvo, saj bo na primer za pripadnike manjšine mogoče, da bodo svoje otroke pošiljali v šole v matično državo, medtem ko se bodo morda slovenski državljani odločali za slovenske šole v Italiji, ker jim bodo te omogočale multikulturnemu prostoru primernejše izobraževanje. Pomembno je nadalje, da si v zadnjem času v italijanskih državnih in lokalnih oblasteh polagoma utira pot zavest, da bi bilo v tem območju potrebno slovenski jezik vključiti v izobraževalni proces ne le manjšinskih, a tudi večinskih šol.

Skratka, slovenska manjšina v Italiji, zlasti pa v Trstu, ki bo nedvomno prevzel posebno vlogo v novi razvijajoči se evroregiji med Italijo, Slovenijo in Hrvaško, se bo v kratkem soočala $\mathrm{z}$ novimi in pomembnimi izzivi. $\mathrm{V}$ tem pogledu je pričakovati, da se bo najprej $\mathrm{V}$ Trstu, kot največjem regionalnem središču in sedežu bodočih čezmejnih integracij v tem delu Evrope, dokaj povečal interes za slovensko kulturo in jezik, v širšem smislu pa "slovanski" svet nasploh. Zato je pomembno in tudi povsem logično, da se tukajšnja slovenska skupnost $\mathrm{z}$ vso svojo razvito in razvejano strukturo pravočasno in dejavno vključi v proces ne le gospodarske, temveč zlasti družbene in kulturne integracije oziroma povezovanja, kjer lahko pač odigra svojo "naravno" posredovalno vlogo tako, da bo ta dobila tudi ustrezno institucionalno podporo. Če bo manjšina znala izkoristiti to priložnost, bo znatno prispevala $\mathrm{k}$ lastni afirmaciji ter širjenju slovenskega jezika in kulture v sosednje države, a tudi k temu, da bo to "najbolj italijansko" mesto odslej vendarle spet nekoliko bolj slovensko, s tem pa veliko bolj "evropsko" in odprto mednarodnim povezavam ter medetnični koeksistenci. Prepričani smo, da bi bilo za to skupnost zelo koristno, ko bi v Trstu nastal in se razvil slovenski kulturni in dokumentacijsko-informacijski center v organizaciji slovenske manjšine v Italiji, kakor bi lahko tudi italijanska manjšina vodila sorodni center v Sloveniji.. S tem bi se obe manjšini 
končno uveljavili kot pravi subjekt v pogledu interetničnega in mednarodnega povezovanja in bi v tem okviru lahko na avtonomen način prevzeli še vrsto drugih pobud na družbenokulturnem področju (Bufon 1994b). Nenazadnje bi v ta sklop sodelovanja smiselno sodilo tudi uresničevanje skupne manjšinske čezmejne televizijske postaje, za katero že obstajajo pobude oziroma dogovori. Tudi na ta način bi tako slovenska manjšina v Italiji kot italijanska v Sloveniji lahko prevzeli novo in širšo institucionalno vlogo spodbujanja in izvajanja družbenih in kulturnih izmenjav med Italijo in Slovenijo ter drugih mednarodnih projektov, vključno s povezovanjem s sorodnimi manjšinami v srednji Evropi.

Osamosvojitev Slovenije ter njen vstop v EU je torej po začetnih težavah in dilemah vendarle sprožila zanimiv proces "evropeizacije" obmejnega prostora in končno položaja slovenske manjšine v Italiji v duhu spoštovanja načel samoodločbe narodov, a tudi potrebe po mednarodni družbeni integraciji in spoštovanju kulturnih različnosti. Vse to nam daje upati, da se bo sedanji slovensko-italijanski obmejni prostor iz območja konfliktov preoblikoval v območje mednarodne koeksistence in sodelovanja (Bufon in Minghi 2000). Za to pa je potreben tudi dejavnejši in pogumnejši pristop same manjšinske skupnosti, ki mora imeti glede lastnega razvoja in perspektiv tudi ustrezno vizijo. Brez nje je usojena na vse večjo emarginacijo na robu tega družbenega prostora, $v$ katerem bo pojem geopolitičnih, meddržavnih in medetničnih meja vse manj zaznaven in določen in kjer se bo ob porastu medkulturnih izmenjav povečalo ne le število "porabnikov", ampak tudi "ponudnikov" tovrstnih storitev.

\section{SKLEP}

Če je bila v preteklosti funkcija slovenske manjšine v Italiji usmerjena predvsem $\mathrm{k}$ gospodarskemu posredovanju med dvema družbeno-političnima različnima državama in sistemoma, je od razkroja Jugoslavije, osamosvojitve Slovenije in poenotenja političnih in družbeno-ekonomskih razmer na obeh straneh meje ta vloga izgubila svoj smisel oziroma se je od mednarodne preusmerila na manjšini bolj prikladno regionalno raven. Vzporedno s tem pa se slovenski manjšini v Italiji, tako kot drugim obmejnim manjšinskim skupnostim v Evropi, odpirajo nove perspektive in nove naloge na področju prekomejne družbene in kulturne integracije in povezovanja (Bufon 1999). To velja še posebej za južni del sedanje slovensko-italijanske meje, ki ga označuje dolgotrajna družbena in kulturna povezanost. V smislu dejanske prekomejne integracije in širjenja načel koeksistence, na katerih temelji ne le proces evropske integracije, temveč sodobna evropska civilizacija nasploh, je ob funkcionalnih aspektih prekomejnih gospodarskih izmenjav zato še posebno pomembno, da se v čim večji meri aktivirajo tudi družbene in kulturne oblike povezovanja in posredovanja. Le na ta način se uspejo oblikovati celovitejša in med seboj integrirana prekomejna območja, kjer meja izgubi svojo tradicionalno delitveno funkcijo in kjer se lahko tudi manjšinske kulturne in jezikovne "kontaktne" skupnosti polneje razvijajo.

V sorodnih zahodno-evropskih obmejnih območjih skušajo zgoraj povedano uresničiti z oblikovanjem posebnih institucionalnih prekomejnih teles, tako imenovanih evroregij, saj gre tam običajno za primere družbeno in kulturno manj prepustnih "starih" obmejnih območij, kjer je treba obmejno prebivalstvo tako rekoč šele privajati k prekomejnemu sodelovanju. 
V našem primeru pa se nahajamo pred situacijo v bistvu "spontanega" čezmejnega prostora, kjer ljudje, kljub pomanjkanju ustreznih institucionalnih nadgradenj, že sedaj nadpovprečno intenzivno prekomejno komunicirajo ne le na gospodarskem, a tudi na družbenem in kulturnem področju. Značilno je tudi, da velik del takih oblik čezmejnega povezovanja tu vzdržujejo ravno manjšine, v prvi vrsti slovenska v Italiji, ki živi vzdolž celotnega mejnega pasu, čeprav za to svojo povsem "naravno", a zato nič manj pomembno funkcijo ne prejema nobenega posebnega priznanja ali spodbudo. Tukajšnje obmejne manjšine se mnogokrat še vedno obravnavajo kot nekakšen "tujek" tako znotraj lastnega družbenega okolja kot v pogledu spodbujanja prekomejnih izmenjav.

Zato bo raziskovanje manjšinske stvarnosti pomenilo obenem raziskovanje družbenokulturnih integracijskih procesov, njihovo spremljanje in usmerjanje (Bufon 2002a). Nova Evropa se bo namreč najprej preverjala in preizkušala ravno v njenih tako številnih obmejnih in etnično mešanih območjih. Vse to pa odpira manjšinam nove priložnosti, a tudi nove izzive, predvsem v reorganizaciji tradicionalnih oblik delovanja in njihovemu prilagajanju novim funkcijam. Izkušnje iz tega in drugih sorodnih obmejnih območij v Evropi nam kažejo, da je dejanska intenzivnost čezmejnih odnosov odvisna ne le od splošnih mednarodnih pogojev, ampak v glavnem od dveh lokalnih dejavnikov: od funkcionalne organizacije samega obmejnega prostora oziroma njegove prilagojenosti potrebam obmejnega prebivalstva po zadovoljevanju osnovnih funkcij na področju oskrbe, dela, izobraževanja, bivanja v skupnosti in preživljanja prostega časa, ter od stopnje družbene in kulturne integracije obmejnega prebivalstva. $\mathrm{V}$ tem pogledu odigravajo etnično mešana obmejna območja posebno vlogo, saj se za razliko od preteklosti, ko so predstavljala potencialno konfliktno stičišče med državami, danes uveljavljajo kot prostori harmoničnega družbenega prepletanja in prelivanja in s tem tudi v vzhodni del srednje Evrope, kjer se zdi odpravljanje političnih meja še vedno nekoliko težavnejše, vnašajo dragocene elemente medetničnega in mednarodnega sožitja (Bufon 2002b). Slovensko-italijansko obmejno območje bi na ta način, upoštevajoč nakazano specifiko oziroma spodbudne lokalne socio-kulturne potenciale, ob podpori obeh zainteresiranih držav in raznih evropskih programov utegnilo biti, tako kot v preteklosti, tudi sedaj zanimiv “laboratorij” za uvajanje novih modelov pri utrjevanju različnih institucionalnih in vsakodnevnih oblik medetnične povezanosti na jugovzhodnem "robu” Evropske unije.

\section{Literatura}

Bufon, M. 1992a: Sedanji evropski razvojni procesi in varstvo manjšin: stari problemi in nove perspektive v luči politične geografije. Geografija v šoli 2. Ljubljana.

Bufon, M. 1992b: Prostorska opredeljenost in narodna pripadnost - obmejna in etnično mešana območja v evropskih razvojnih silnicah : primer Slovencev v Italiji. ZTT. Trst.

Bufon, M. 1994a: Manjšine v sodobnih razvojnih procesih: primer Slovencev v Italiji. V: Vencelj, P., Klemenčič V. in Novak Lukanovič, S. (ur.): Manjšine v prostoru Alpe-Jadran. Delovna skupnost Alpe-Jadran in Vlada Republike Slovenije. Ljubljana.

Bufon, M. 1994b: Nacionalne manjšine in njihova funkcija v mednarodnih integracijskih procesih : iluzija ali realnost? V: Štrukelj, I. in Sussi, E. (ur.): Narodne manjšine danes in jutri. SLORI. Trst. 
Bufon, M. 1997: Prostorski aspekti manjšinske problematike v luči slovenskega socialnogeografskega in političnogeografskega proučevanja. Dela 12. Ljubljana.

Bufon, M. 1998: Procesi evropske integracije in ohranjanje jezika narodnih manjšin. V: Štrukelj, I. (ur.): Jezik za danes in jutri. Društvo za uporabno jezikoslovje Slovenije in Inštitut za narodnostna vprašanja. Ljubljana.

Bufon, M. 1999: Evropski manjšinski jeziki med standardizacijo in novimi razvojnimi perspektivami. Annales 9/1. Koper.

Bufon, M. 2000a: Slovenska manjšina v Italiji med lokalnimi in globalnimi razvojnimi procesi. V: Pahor, S., Martelanc, S. in Maver, M. (ur.): Med zgodovino in sedanjostjo. Mladika, Trst.

Bufon, M. 2000b: Med socio-kulturno pluralnostjo in socio-ekonomsko integracijo: problemi in perspektive modela ,združenosti v različnosti““ v zgornjejadranskem kontaktnem prostoru. V: Štrukelj, I. (ur.): Kultura, identiteta in jezik v procesih evropske integracije. Društvo za uporabno jezikoslovje. Ljubljana.

Bufon, M. 2002a: Aplikativni vidiki politične geografije v planiranju integracije in razvoja kontaktnih prostorov. Dela 18. Ljubljana.

Bufon, M. 2002b: Confini, identita' ed integrazione. SLORI. Trieste.

Bufon, M. 2003: Minorities, regional transformation and integration in borderlands: a case study. Annales 13/1. Koper.

Bufon. M. 2005: Političnogeografski učinki mirovnega sporazuma in Londonskega memoranduma na slovensko-italijansko obmejno območje. V: Pirjevec, J., Bajc, G. in Klabjan, B. (ur.): Vojna in mir na Primorskem: od kapitulacije Italije leta 1943 do Londonskega memoranduma leta 1954. Univerza na Primorskem. Koper.

Bufon, M. in Minghi, J. 2000: The Upper Adriatic borderland: from conflict to harmony. GeoJournal 52/2. Utrecht.

Klemenčič, V. in Bufon, M. 1991: Geographic problems of frontier regions: the case of the Italo-Yugoslav border landscape. V: Rumley, D. in Minghi, J. (ur.): The Geography of Border Landscapes. Routledge. London.

Klemenčič, V. in Bufon, M. 1994: Cultural elements of integration and transformation of border regions: the case of Slovenia. Political Geography 13/1. Oxford.

\section{STUDY OF MINORITIES AND BORDER AREAS IN THE UPPER ADRIATIC: RESEARCH APPROACHES AND PROBLEMS IN LIGHT OF POLITICAL GEOGRAPHY}

\section{Summary}

Proceeding from the methodological-theoretical starting point established for Slovene geography by Professor Vladimir Klemenčič, the author deals with the complexity of minority and border issues that make up the problem of studying contact areas in the upper Adriatic. The nexus of these issues is under the simultaneous influence of various factors, which presenta 
a sort of hierarchic arrangement of social and spatial relations between the minority and its social environment and can be categorized as follows:

- geopolitical situation;

- inter-state relations;

- inter-ethnic relations;

- internal development factors.

On the example of the mentioned contact area the author further on discusses the different phenomenon typologies within the social dominance-minority relation, which is comprised of the situations of border national minority, territorial or regional minority and urban minority. At the same time he reflects on the contemporary development dilemmas concerning the relations between the different statuses of minority situations and referring to the conditions of urban or 'immersed' minority, territorial or virtual minority, national or ethnic minority, and acknowledged or tolerated minority. The author then places the problem of development dynamics of contact areas in the context of the relation between centres and peripheries and of the results of socio-geographic studies in Slovenia, with an emphasis on the function of local communities and national minorities as well as the models of ethnic-regional development. The paper concludes with an overview of various typifications of border areas according to the role of local communities and minorities in the formation of different systems of crossborder communication. The author finds that the upper Adriatic has once again proven to be a most interesting "laboratory" for the introduction of new models in the consolidation of various institutional and everyday forms of inter-ethnic and inter-state integration within the framework of the European Union. 